\title{
Antimicrobial activity of Palestinian medicinal plants against acne-inducing bacteria
}

\author{
Mohammed S. Ali-Shtayeh ${ }^{1,2 *}$, Anhar Ahmad Al-Assali ${ }^{2}$ and Rana Majed Jamous ${ }^{1}$ \\ ${ }^{1}$ Biodiversity and Environmental Research Center, BERC, Til, Nablus, Palestine, Israel. \\ ${ }^{2}$ An-Najah University, Nablus, Palestine, Israel.
}

Accepted 3 May, 2013

\begin{abstract}
The antimicrobial activities of 56 Palestinian medicinal plants against etiologic agents of acne vulgaris, mainly Propionibacterium acnes and Staphylococcus aureus was studied using disc diffusion and broth dilution methods. The results from the disc diffusion method demonstrated that these plants differ significantly in their activity against the studied microorganisms. The most active plants against all bacterial strains were Rhus coriaria, Ricinus communis, and Sarcopoterium spinosum. Test microorganisms differed significantly in relation to their susceptibility to different plant extracts used. Generally, anaerobic bacteria were more susceptible to plant extracts than aerobic bacteria. Those plants which could inhibit the growth of $P$. acnes, $R$. coriaria, $R$. communis, and $S$. spinosum had strong inhibitory effects. 43 plants could inhibit the growth of all aerobic bacteria. Based on a broth dilution method, the $R$. coriaria extract had the greatest antimicrobial effect against $P$. acnes (MIC 6 $\mathrm{mg} / \mathrm{ml}$, MBC $6 \mathrm{mg} / \mathrm{ml}$ ), S. aureus (MIC $4 \mathrm{mg} / \mathrm{ml}$, MBC $6 \mathrm{mg} / \mathrm{ml}$ ), E. coli (MIC $6 \mathrm{mg} / \mathrm{ml}, \mathrm{MBC} 8 \mathrm{mg} / \mathrm{ml}$ ) and $P$. aeruginosa (4 and $6 \mathrm{mg} / \mathrm{ml}$ ). Taken together, our data indicate that $R$. coriaria, $R$. communis had a strong inhibitory effect on $P$. acnes and most other test bacteria. Therefore, the two plants would be an interesting topic for further study and possibly for an alternative treatment for acne.
\end{abstract}

Key words: Acne, Propionibacterium acnes, Staphylococcus aureus, Echerichia coli, Klebsiella pneumonia, Proteus vulgaris, antimicrobial activity.

\section{INTRODUCTION}

Acne vulgaris is a chronic inflammatory disease of the pilosebaceous unit, resulting from androgen-induced increased sebum production, inflammation, altered keratinisation, and bacterial collonisation of hair follicles on the face, neck, chest, and back by Propionibacterium acnes (Williams et al., 2012). Acne is characterized by comedones, papules, pustules, cysts, nodules and often scars in certain sites of predilection, namely, the face, neck, upper trunk and arms.

As a family of skin disorders, acne is one of the most prevalent dermatologic diseases in the world. It usually affects almost everybody during the life (Scheinfeld,
2007). It affects all most all people aged 15 to 17 years (Rademaker et al., 1989; Law et al., 2010; Yahya, 2009), and is moderate to severe in 15 to $20 \%$ (Williams et al., 2012). The pathogenesis of the disease is complex but dependent on several factors including androgenmediated stimulation of sebaceous gland activity, colonization of the bacterium $P$. acnes (an anaerobic bacterium as a normal constituent of the skin microbial flora), and inflammation (Toyoda and Morohashi, 2001).

The use of natural remedies dates back thousands of years. It is estimated that there are 250,000 to 500,000 species of plants on Earth (Borris, 1996), and 2780 
species of plants in the Palestinian authority territory (AliShtayeh and Jamous, 2002) which offers a great hope in the identification of phytotherapeutic agents and their development into drugs for the treatment of acne vulgaris that affects approximately $80 \%$ of the population between the ages of 12 to 25 years (Ghosh et al., 2011).

The interest in beauty is natural, and cosmetics are as ancient as mankind and civilization (Gediya et al., 2011). Therefore, acne vulgaris, which can persist into adulthood, could suppress an individual's self-confidence with regard to physical appearances or even depression that may affect all aspects of life. In view of increasing resistance to existing anti-microbial agents, side effects and sometimes high cost of treatment (Oprika, 2006; Ghosh et al., 2011; Hamburger and Hostettmann, 1991), discovering an effective treatment for acne that is well tolerated by the patients is a challenge.

Singh et al. (2011) reviewed the possible correlation between antimicrobial activities of medicinal plants against the etiologic agents of acne vulgaris. They found that different parts of various medicinal plants belonging to families like Liliaceae, Rutaceae, Zingiberaceae, Myrtaceae, Lamiaceae, etc contain alkaloids, tannins, flavonoids, terpenoids, volatile oil and essential oil which are reported with significant effect against this bacteria.

The development of resistance by a pathogen to many of the commonly used antibiotics provides and impetus for further attempts to search for new antimicrobial agents to combat infections and overcome the problems of resistance and side effects of the currently available antimicrobial agents. Hence, this in vitro study was aimed at screening selected Palestinian plants for their antimicrobial activity against Propionibacterium acnes, and determine whether their use in folkloric medicine to treat these infections is justified.

\section{MATERIALS AND METHODS}

\section{Preparation of plant extracts}

Plant parts of 56 plants used in traditional Arabic Palestinian herbal medicine (TAPHM) for the treatment of acnes and other skin disorders were collected from various locations in Palestine (West Bank). Authentification of the plants was done by comparison with plant specimens located at BERC Herbarium and the Biodiversity and Biotechnology Research Unit, BERC, Nablus, Palestine. Voucher specimens of the plants were deposited at BERC Herbarium, Til, Nablus, Palestinian Authority (Table 1).

\section{Microorganisms and media}

The microorganisms used included: $P$. acnes (ATCC 6919, ATCC 6921), and eight other strains of this microorganism isolated from different clinical specimens recovered from acne patients and identified using standard procedures. Five medically important bacterial strains were also included (Staphylococcus aureus ATCC 25923; Escherichia coli ATCC 25922; Klebsiella pneumonia ATCC 13883; Proteus vulgaris ATCC 13315; and Pseudomonas aeruginosa ATCC 27853). All media were purchased from DIFCO (Detroit, MI).

\section{Antimicrobial susceptibility testing}

\section{Disk diffusion method}

This experiment was carried out by the method of Hayes and Markovic (2002) with some modifications. P. acnes was incubated in liquid Reinforced Clostridium Medium (RCM) for $48 \mathrm{~h}$ under anaerobic conditions and adjusted to yield approximately $1.0 \times 10^{8}$ $\mathrm{CFU} / \mathrm{ml}$. A $1.0 \times 10^{8} \mathrm{CFU}$ inoculum was spread on blood agar (with sheep blood 5 to 7\%) (BASB) medium plates. Discs of $6 \mathrm{~mm}$ diameter were prepared from Whatman filter paper No.1, placed in a glass Petri dishes and autoclaved for $15 \mathrm{~min} .25 \mu \mathrm{l}$ of the required extract were added to each sterile disc, and the discs were dried under a laminar flow sterile bench. The final content of each disc was $5 \mathrm{mg}$ of extract. A sterile paper disc impregnated with test material was placed on the agar. Plates were then incubated at $37^{\circ} \mathrm{C}$ for $72 \mathrm{~h}$ under anaerobic conditions (in Gas Pak Jars).

Aerobic bacteria were incubated in Muller-Hinton broth (MHB) for $24 \mathrm{~h}$ at $37^{\circ} \mathrm{C}$ and adjusted to yield approximately $1.0 \times 10^{8} \mathrm{CFU} / \mathrm{ml}$. The procedures were the same as mentioned above except the plates were incubated at $37^{\circ} \mathrm{C}$ for $24 \mathrm{~h}$ under aerobic conditions.

All disc diffusion tests were performed in three separate experiments and the antibacterial activity was expressed as the mean inhibition zone diameters, IZD $(\mathrm{mm})$ and relative antibacterial activity.

On each plate an appropriate reference antibiotic disc was applied depending on the test microorganism. Ampicillin, Gentamicin, Gentamicin, Ciprofloxacin, Penecillin G, and chloramphenicol served as positive control for E. coli, $P$. vulgaris, $P$. aeruginosa, K. pneumonia, $S$. aureus and $P$. acnes, respectively.

\section{Determination of minimum inhibitory and bactericidal concentrations}

The minimal inhibitory concentration (MIC) values were determined by broth dilution assay (Murray et al., 1995). The cultures were prepared at 24 and $48 \mathrm{~h}$ broth cultures of aerobic bacteria, and $P$. acnes, respectively. The MIC was defined as the lowest concentration of the compound to inhibit the growth of microorganisms and the minimum bactericidal concentration (MBC) was defind as the lowest concentration of the compound to kill the microorganisms. A stock solution $(200 \mathrm{mg} / \mathrm{ml})$ of plant extract was prepared in $10 \%$ DMSO. Several aliquots of the stock solution were prepared $(0.2,0.1,0.075,0.05,0.04,0.03$, and $0.02 \mathrm{ml})$. The aliquots were made up to $0.2 \mathrm{ml}$ each by adding $0.0,0.1,0.125$, $0.15,0.16,0.17,0.18 \mathrm{ml}$ DMSO, respectively. For each strain, 10 tubes each with $9.7 \mathrm{ml}$ MHB for aerobic bacteria and $9.7 \mathrm{ml} \mathrm{RCM}$ for anaerobic bacteria were prepared and autoclaved. $0.2 \mathrm{ml}$ of each of the above concentrations was added to 7 of the 10 broth tubes to obtain the following dilutions $(\mathrm{mg} / \mathrm{ml}): 40,20,15,10,8,6$, and 4 , respectively. One of the remaining three tubes was used as a positive control by adding $0.2 \mathrm{ml}$ of reference antibiotic solution $(100 \mathrm{mg} / \mathrm{ml})$, whereas the other two tubes were used as negative control by adding $0.2 \mathrm{ml}$ of DMSO to one tube and $0.2 \mathrm{ml}$ sterile water to the other. All tubes were inoculated with $0.1 \mathrm{ml}$ of the test suspension $(10 \mathrm{CFU} / \mathrm{ml})$. The tubes were then incubated for $24 \mathrm{~h}$ at $37^{\circ} \mathrm{C}$ for the aerobic bacteria and $48 \mathrm{~h}$ at $37^{\circ} \mathrm{C}$ in Gas Pak Jars for the anaerobic bacteria (Murry et al., 1995). After incubation, the MIC of each ingredient was determined by visual inspection of the tubes. The lowest concentration of the active ingredient that inhibited growth of the organism, as detected by lack of visual turbidity (matching the negative growth control) was designated the MIC (Baron et al., 1994).

For minimum bactericidal concentration (MBC), subcultures were made from the visually clear tubes of inoculum with antimicrobial agent (active plants) on MHA plate for aerobic bacteria, and on BASB for anaerobic bacteria. MBC was interpreted to be at a 
Table 1. Selected plants used for antibaterial succeptibility testing against $P$. acnes and aerobic bacteria.

\begin{tabular}{|c|c|c|c|c|}
\hline Latin name & Family name & English name & Plant part used ${ }^{*}$ & Medicinal uses \\
\hline Achillea fragrantissima Forssk. & Compositae & Yarrow & $\mathrm{AP}, \mathrm{FL}$ & $\begin{array}{l}\text { Skin, hair, and burns, headache and } \\
\text { temperature, cancer, circulatory system, } \\
\text { kidney and urinary tract system, weight 1, 2, 3, 9, } 10 \\
\text { loss, digestive system, food poisoning, } \\
\text { diabetes }\end{array}$ \\
\hline Ajuga orientaslis L. & Lamiaceae & Eastern Bugle & AP & Skin ailments \\
\hline Allium sativum $\mathrm{L}$. & Liliaceae & Garlic & LF & $\begin{array}{l}\text { Weight gain, tooth inflammation, ear } \\
\text { diseases, weight loss, skin, hair, and } \\
\text { burns, reproductive system, respiratory } \\
\text { system, nervous system, skeletal and 1, 2, 3, 6, 9, 11, } 12 \\
\text { muscular system, digestive system, } \\
\text { cancer, circulatory system, kidney and } \\
\text { urinary, tract system, diabetes }\end{array}$ \\
\hline Arum dioscorides Sibth \& Sm & Araceae & Spotted Arum & LF & $\begin{array}{l}\text { Circulatory system, diabetes, cancer, } 1,2,12,9 \\
\text { digestive system }\end{array}$ \\
\hline Asparagus aphyllus L. & Liliaceae & Prickly Asparagus & AP & Kidney and urinary tract system, cancer $1,6,9,11$ \\
\hline Capparis spinosa L. & Capparidaceae & Caper Bush & $\mathrm{FR}, \mathrm{FL}$ & $\begin{array}{l}\text { Ear diseases, eye diseases, } \\
\text { reproductive system, respiratory system, } 1,2,3,4,5,6,7,9 \\
\text { skeletal and muscular system, kidney } \\
\text { and urinary tract system }\end{array}$ \\
\hline Cardaria draba L.) Desv. & Brassicaceae & $\begin{array}{l}\text { Heart-Podded } \\
\text { Cress }\end{array}$ & Hoary AP & 6 \\
\hline Ceratonia siliqua L. & Caesalpiniaceae & Carob & $\mathrm{S}$ & $\begin{array}{l}\text { Diabetes, tooth inflammation, weight } \\
\text { loss, skin, hair, and burns, respiratory } 1,2,3,6,7,9,10,11 \text {, } \\
\text { system, digestive system, diabetes, } 12 \\
\text { circulatory system, cancer }\end{array}$ \\
\hline Chrysanthemum coronarium L. & Compositae & Corn Marigold & $\mathrm{FL}$ & $\begin{array}{l}\text { Respiratory system, digestive system, 1, 2, } 6 \\
\text { circulatory system }\end{array}$ \\
\hline Cicer arietinum L. & Fabaceae & Chick Pea & AP & $\begin{array}{l}\text { Kidney and urinary tract system, } \\
\text { digestive system, reproductive system, } 9,1,10,12 \\
\text { skin, hair, and burns, weight gain, } \\
\text { diabetes }\end{array}$ \\
\hline Clematis cirrhosa $\mathrm{L}$. & Ranunculaceae & $\begin{array}{l}\text { Evergreen } \\
\text { Power }\end{array}$ & Virgin's- $A P$ & $1,2,3,4,5,6$ \\
\hline
\end{tabular}


Table 1. contd.

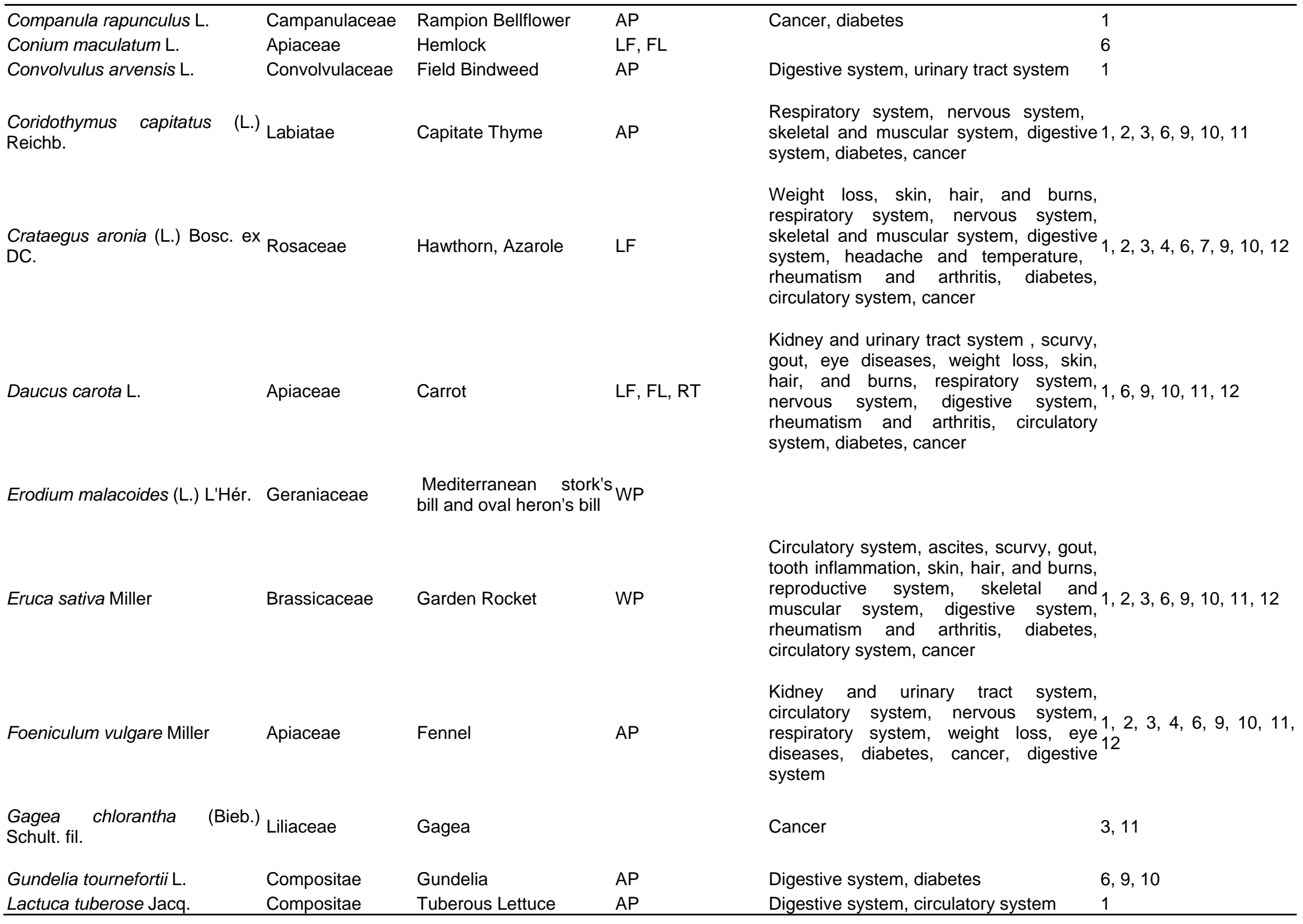


Table 1. contd.

$\begin{array}{llll}\text { Linum pubescens Banks \& Sol. } & \text { Linaceae } & \text { Pink Flax } & \text { AP, } \\ \begin{array}{lll}\text { Lupinus pilosus L. (Lupinus varius L.) } \\ \text { Lycium europaeum L. }\end{array} & \begin{array}{l}\text { Papilionaceae } \\ \text { Solanaceae }\end{array} & \begin{array}{l}\text { Blue Lupine } \\ \text { Mediterranean tea tree AP }\end{array} \\ & \text { Labiatae } & \begin{array}{l}\text { Wild Thyme, Mother of AP } \\ \text { Thyme }\end{array}\end{array}$

Mandragora autumnalis Bertol.

Solanaceae

Mandrake

Mentha spicata L.

Notobasis syriaca (L.) Cass. Parietaria judiaca $L$.

Paronychia argentea Lam.

Petroselinum sativum Hoffm.

Apiaceae

Parsley

WP

Phagnalon rupestre (L.) DC.

Compositae

Pinus halepensis Mill.

Pinaceae

African Fleabane, Rock AP
Phagnalon

Aleppo Pine

Pistacia lentiscus L.
Anacardiaceae Lentisk, Mastic Tree LF
Weight loss, skin, hair, and burns, respiratory system, skeletal and muscular system, digestive system, 1, 2, 2, 3, 6, 9, 10, 11 headache and temperature, kidney and

urinary tract system, diabetes, cancer

Circulatory system, eye diseases, weight loss, skin, hair, and burns, reproductive system, respiratory system, nervous system, skeletal and muscular system, 1, 2, 6, 9, 10, 11, 12 digestive system, headache and temperature , circulatory system, kidney and urinary tract system, tooth inflammation, diabetes, cancer

Digestive system, respiratory system, 1 weight loss, respiratory system,

$\begin{array}{ll}\text { Nervous system } & 1 \\ \text { Cancer } & 3,4,5,6,11\end{array}$

Digestive system, weight loss, respiratory system, skeletal and 1, 2, 3, 5, 6, 9, 10, 11, muscular system, digestive system, 12 diabetes, cancer, urinary tract system

Circulatory system, digestive system, diabetes, cancer, reproductive system, $1,9,11,12$ reproductive system, kidney and urinary tract system

Weight loss, skin, hair, and burns, $1,2,3,4,5,6,9,11,12$ skeletal and muscular system, cancer

Reproductive system, respiratory $1,2,3,5,6,7,9,12$

Reproductive system, respiratory
system, skin, hair, and burns, digestive system, skin, hair, and burns, digestive 1, 2, 7, 9, 12 rheumatism and arthritis, paralysis 
Table 1. contd

\begin{tabular}{|c|c|c|c|c|}
\hline Pyrus syriaca Boiss & Rosaceae & Syrian Pear & $\mathrm{LF}, \mathrm{FL}$ & $\begin{array}{l}\text { Digestive system, food poisoning, kidney } \\
\text { and urinary tract system, circulatory } 1,2,6,7,9 \\
\text { system }\end{array}$ \\
\hline Reseda alba L. & Resedaceae & White mignonette & WP & \\
\hline Rhus coriaria L. & Anacardiaceae & Sicilian Sumach & AP & $\begin{array}{l}\text { Weight loss, tooth inflammation, skin, } \\
\text { hair, and burns, digestive system, 1, 2, 3, 6, 7, } 9 \\
\text { headache and temperature, diabetes }\end{array}$ \\
\hline Ricinus communis L. & Euphorbiaceae & Castor Beans & AP & $\begin{array}{l}\text { Kidney and urinary tract system, ear } \\
\text { diseases, eye diseases, food poisoning, } \\
\text { skin, hair, and burns, reproductive } \\
\text { system, respiratory system, skeletal and 1, 2, 3, 6, 7, 9, 11, } 12 \\
\text { muscular system, digestive system, } \\
\text { rheumatism and arthritis, paralysis, bites, } \\
\text { stings, cancer }\end{array}$ \\
\hline Rosa centifolia L. & Rosaceae & Pale Rose & $\mathrm{FL}$ & $\begin{array}{l}\text { Bites and stings, respiratory system, eye } \\
\text { diseases, digestive system, skin, hair, 1, 9, 11, } 12 \\
\text { and burns, cancer }\end{array}$ \\
\hline Rubia tenuifolia D'Urv. & Rubiaceae & Narrow-Leaved Madder & AP & Kidney and urinary tract system $\quad 1,3,6$ \\
\hline Ruta chalepensis L. & Rutaceae & Rue & $\mathrm{AP}, \mathrm{FL}$ & $\begin{array}{l}\text { Ear diseases, skin, hair, and burns, } \\
\text { respiratory system, nervous system, } \\
\text { skeletal and muscular system, digestive 1, 2, 2, 3, 4, 5, 6, 7, 9, } \\
\text { system, headache and temperature, 12 } \\
\text { kidney and urinary tract system, } \\
\text { paralysis }\end{array}$ \\
\hline Saccharum ravennae $\mathrm{L}$. & Poaceae & Ravenna grass & FL & \\
\hline Salvia fruticosa Mill. & Labiatae & $\begin{array}{l}\text { White Sage, Common, } \\
\text { Sage, Garden Sage }\end{array}$ & LF & $\begin{array}{l}\text { Weight loss food poisoning, skin, hair, } \\
\text { and burns, reproductive system, } \\
\text { respiratory system, nervous system, } 1,2,3,4,5,6,7,9,10 \text {, } \\
\text { diabetes, circulatory system, kidney and } 11,12 \\
\text { urinary tract system, headache and } \\
\text { temperature, digestive system, tooth } \\
\text { inflammation, cancer }\end{array}$ \\
\hline Salvia hierosolymitana Boiss. & Labiatae & Jerusalem Sage & LF & $\begin{array}{l}\text { Kidney and urinary tract system, 1, 6, } 9 \\
\text { circulatory system, digestive system }\end{array}$ \\
\hline Sarcopoterium spinosum (L.) Sp. & Rosaceae & Shruppy Barnet & AP & Diabetes, tooth inflammation \\
\hline Satureja thymbra L. & Labiatae & Summer Savory & $\mathrm{AP}, \mathrm{FL}$ & $2,3,6$ \\
\hline
\end{tabular}


Table 1. contd.

\begin{tabular}{|c|c|c|c|c|}
\hline Scabiosa prolifera L. & Dipsacaceae & Carmel daisy & AP & 6,8 \\
\hline Sinapis arvensis L. & Brassicaceae & Mustard/ Wild & WP & $1,2,11$ \\
\hline Spinacia oleraceae L. & Chenopodiaceae & Spinach & WP & $\begin{array}{l}\text { Kidney and urinary tract system, } \\
\text { respiratory system, digestive system, 1, 2, 3, 9, } 12 \\
\text { circulatory system }\end{array}$ \\
\hline Styrax officinalis & Styracaceae & Storax & YB & \\
\hline $\begin{array}{l}\text { Trigonella berythea Boiss. } \\
\text { Blanche ( } T \text {. foenum-graecum L.) }\end{array}$ & \& Fabaceae & Fenugreek Seed, & AP & $\begin{array}{l}\text { Kidney and urinary tract system, tooth } \\
\text { inflammation, weight loss, skin, hair, and } \\
\text { burns, reproductive system, respiratory } \\
\text { system, nervous system, skeletal and } 1,2,3,6,9,10,11,12 \\
\text { muscular system, digestive system, } \\
\text { rheumatism and arthritis, diabetes, } \\
\text { circulatory system, kidney and urinary } \\
\text { tract system, cancer }\end{array}$ \\
\hline $\begin{array}{l}\text { Varthemia iphionoides Boiss } \\
\text { Blanche (Chiliadenus iphionoide } \\
\text { (Boiss. \& Blanche) Brullo) }\end{array}$ & $\begin{array}{l}\text { \& } \\
\text { es Compositae }\end{array}$ & Common varthemia & AP & $\begin{array}{l}\text { Circulatory system, diabetes, digestive } 1,2,3,6,9,10,12 \\
\text { system, respiratory system, weight loss }\end{array}$ \\
\hline Vicia faba L. & Leguminosae & Broadbean & AP & $\begin{array}{l}\text { Kidney and urinary tract system, } \\
\text { circulatory system, diabetes, digestive 1, 2, 3, 6, 9, 10, } 12 \\
\text { system }\end{array}$ \\
\hline Viscum cruciatum Sieber \& Bioss & Santalaceae & Mistletoe & LF & Cancer, circulatory system \\
\hline
\end{tabular}

tube that showed no growth on agar plate (Irobi and Daramala, 1994).

\section{Statistical analysis}

Data of the susceptibility test were analysed by three way analysis of variance (ANOVA) with $95 \%$ confidence $(P<0.05)$. Determination of relative antimicrobial activity $=[\text { (inhibition zone diameter mean of active plant })^{2} /$ (inhibition zone diameter mean of reference antibiotics) $\left.{ }^{2}\right]$ $\times 100 \%$.

\section{RESULTS}

\section{Antimicrobial activity of 56 plants}

The present study was conducted to evaluate antimicrobial activities of Palestinian medicinal plants against etiologic agents of acne vulgaris, mainly $P$. acnes (Gram-positive). Crude ethanolic extracts of 56 plant species used in folk medicine in Palestine for treatment of several infections and diseases (Table 1) were investigated for their antimicrobial activities against 10 strains of $P$. acnes, and five Gramnegative strains of aerobic bacteria, $E$. coli, $K$. pneumonia, $P$. vulgaris and $P$. aeruginosa; and one Gram-positive bacterium $S$. aureus, using two susceptibility tests: the disk diffusion method for measuring the antimicrobial activity, and broth method for the determination of MIC and $\mathrm{MBC}$ for the active plant extracts. 
Based on the disc diffusion method and related relative antimicrobial activity values (RAA) (Tables 2 and 3), four $(7.1 \%)$ of the studied plants had high RAA ( $\geq 60$; IZD range 20.8 to 25.0 ), and seven (12.5\%) had medium (30 to 60; IZD range 11.7 to 15) activity against $P$. acnes. 39 $(69.6 \%)$ of the plants showed low (RAA $<30 ;$ IZD $>6$ to $10.7)$ activity and six (10.7\%) showed no detectable activity against $P$. acnes (Table 3 and Figure 1). On the other hand, only 1 , and 4 of the plants had high activity against only $P$. aeruginosa and $E$. coli, respectively (Tables 2 and 3). Also four, 17, one, and one of the plants had medium activity against $S$. aureus, E. coli, $P$. aeruginosa, and $P$. vulgaris, respectively. $20(35.7 \%)$ to $41(73.2 \%)$ plant species showed low activity, and 6 to 18 $(10.7$ to $32.1 \%)$ species showed no detectable antimicrobial activity against one or more of the studied aerobic bacterial species (Table 3 and Figure 1).

On the basis of RAA values $(\geq 30)$, the most active plants against test bacteria (19 plants, 33.9\%), were $R$. coriaria (RAA 153), R. communis (153), Sarcopoterium spinosum (120), Sinapis arvensis (100), and Pinus halepensis (59) against $P$. acnes (Table 4); R. coriaria (58), R. communis (42), S. spinosum (40), and Viscum cruciatum (36) against $S$. aureus; $R$. coriaria (215), $V$. cruciatum (149), R. communis (144), Satureja thymbra (64), Majorana syriaca (54), S. spinosum (53), Vicia faba (44), Crataegus aronia (44), Capparis (42), S. arvensis (42), Lactuca tuberosa (42), Trigonella berythea (39), Coridothymus capitatus (36), Convolvulus arvensis (36), Conium maculatum (33), Pyrus syriaca (33), Phagnalon rupestre (31), and Rosa centifolia (31) against E. coli; $R$. coriaria (77), and $R$. communis (52) against $P$. aeruginosa; $R$. coriaria (30) against $P$. vulgaris (Table 5). However, $R$. communis (21) was the most active plant against $K$. pneumonia.

All plants studied in this work differed significantly in their activity against the test microorganism $(F=51.317$, DF $=839, \mathrm{P}<0.05)$.

\section{Susceptibility of test bacterial strains to plant extracts}

Test strains differed significantly in their susceptibility to the different plant extracts used $(F=2.078, D F=839, P$ $<0.05)$. The most sensitive test microorganism was $P$. acnes, followed by $S$. aureus, E. coli, $P$. aeruginosa, $P$. vulgaris and $K$. pneumonia with inhibition zone diameter means of 9.8, 9.2, 8.4, 8.4 and 7.8.

Based on the numbers of plants with high and medium activities against the different aerobic bacteria spp, E. coli was the most susceptible species, whereas $K$. pneumonia was the least susceptible to the studied plants (Table 3 and Figure 1).

\section{MIC and MBC of the active plant extracts}

Based on MIC and MBC results, $P$. acnes (anaerobic bacteria), was shown to be the most susceptible microorganisms with MIC raging from 6 to $29 \mathrm{mg} / \mathrm{ml}$ and $\mathrm{MBC}$ from 6 to $31.6 \mathrm{mg} / \mathrm{ml}$, and with $R$. coriaria showing the lowest MIC $(6 \mathrm{mg} / \mathrm{ml})$ and MBC $(6 \mathrm{mg} / \mathrm{ml})$ whereas $V$. cruciatum had the highest MIC $(28 \mathrm{mg} / \mathrm{ml})$ and MBC (30 $\mathrm{mg} / \mathrm{ml}$ ) (Table 4).

For aerobic bacteria, the most susceptible microorganism was $S$. aureus with MIC ranging from 4 to $18 \mathrm{mg} / \mathrm{ml}$ and $\mathrm{MBC}$ from 6 to $21 \mathrm{mg} / \mathrm{ml}$, and the least susceptible microorganism was $K$. pneumonia with MIC ranging from 11 to $25 \mathrm{mg} / \mathrm{ml}$ and MBC 15 to $30 \mathrm{mg} / \mathrm{ml}$. $R$. coriaria had the lowest MIC $(4 \mathrm{mg} / \mathrm{ml})$, while $L$. tuberosa, and $V$. cruiciatums had the highest MIC $(>25 \mathrm{mg} / \mathrm{ml})$ (Table 5).

\section{DISCUSSION}

The results of the antimicrbial screening assay of crude extracts of all species of plants showed that the most active plants against all bacterial strains were $R$. coriaria, $R$. communis and $S$. spinosum. All species of plants included in the present study (except Arum discorides, Ceratonia siliqua, Paronychia argentia) were also found to be active on at least one of the tested bacterial strains. In general, among the tested bacterial strains, $P$. acnes was found to be more sensetive to plant extracts than other aerobic bacteria. On the other hand, K. pneumonia was the most insensitive of all the bacteria used in this study. The antimicrobial activity was more pronounced on the Gram-positive bacteria ( $P$. acnes and $S$. auereus) than the Gram-negative bacteria ( $E$. coli and $P S$. aeruginosa). In fact, Gram-negative bacteria are frequently reported to have developed multi drug resistance to many of the antibiotics currently available in the market (Alonso et al., 2000; Sader et al., 2002). The reason for the difference in sensitivity between Gram +ve and Gram -ve bacteria might be ascribed to the differences in morphological constitutions between these micoorganisms: Gram -ve bacteria have an outer phospholipidic membrane carrying the structural lipopolysaccharide components. This makes the cell wall impermeable to antimicrobial chemical substances. The Gram +ve bacteria on the other hand are more susceptible having only an outer peptidoglycan layer which is not an effective permeability barrier. Therefore, the cell walls of Gram-negative organisms which are more complex than the Gram-positive ones act as a diffusional barrier and making them less susceptible to the antimicrobial agents than are Gram +ve bacteria (Nostro et al., 2000; Hodges, 2002). In spite of this permeability differences, however, some of the extracts have still exerted some degree of inhibition against Gram -ve organisms as well.

Reports (Arda, 2009) indicate that acne is common among dermatology patients (9 to 12\%) in the West Bank (Palestinian Authority territory). Thus, the fact that 50 species of the tested plants (89\%) showed activity 
Table 2. Relative antimicrobial activity* of plants against $P$. acnes and aerobic bacteria.

\begin{tabular}{|c|c|c|c|c|c|c|}
\hline Latin name & P. acnes* & S. aureus & E. coli & P. aeruginosa & P. vulgaris & K. pneumonia \\
\hline Achillea fragrantissima Forssk. & 14 & 7 & 26 & $6 *$ & 8 & $4 *$ \\
\hline Ajuga orientaslis L. & 30 & 7 & 26 & 10 & 7 & 4 \\
\hline Allium sativum $\mathrm{L}$. & 15 & 8 & 33 & 13 & 13 & 8 \\
\hline Arum dioscorides Sibth \& Sm & 8 & $4 *$ & $16 *$ & 6 & $6 *$ & 4 \\
\hline Asparagus aphyllus L. & 14 & 4 & 16 & 6 & 6 & 4 \\
\hline Capparis spinosa L. & 10 & 29 & 42 & 10 & 14 & 9 \\
\hline Cardaria draba (L.) Desv. & 8 & 5 & 28 & 7 & 6 & 5 \\
\hline Ceratonia siliqua L. & 8 & 4 & 16 & 6 & 6 & 4 \\
\hline Chrysanthemum coronarium L. & 15 & 7 & 16 & 12 & 10 & 4 \\
\hline Cicer arietinum $\mathrm{L}$. & 15 & 5 & 16 & 8 & 9 & 7 \\
\hline Clematis cirrhosa L. & 26 & 7 & 28 & 10 & 10 & 7 \\
\hline Companula rapunculus $\mathrm{L}$. & 18 & 4 & 16 & 6 & 6 & 4 \\
\hline Conium maculatum $\mathrm{L}$. & 11 & 10 & 33 & 6 & 9 & 6 \\
\hline Convolvulus arvensis L. & 15 & 8 & 36 & 12 & 10 & 7 \\
\hline Coridothymus capitatus (L.) Reichb. & 15 & 9 & 36 & 12 & 13 & 8 \\
\hline Crataegus aronia (L.) Bosc. ex DC. & 14 & 15 & 44 & 23 & 16 & 11 \\
\hline Daucus carota L. & 8 & 6 & 22 & 13 & 13 & 5 \\
\hline Erodium malacoides (L.) L'Hér. & 21 & 6 & 33 & 14 & 13 & 9 \\
\hline Eruca sativa Miller & 14 & 7 & 28 & 8 & 6 & 4 \\
\hline Foeniculum vulgare Miller & 12 & 6 & 16 & 10 & 9 & 7 \\
\hline Gagea chlorantha (Bieb.) Schult. fil. & 10 & 4 & 22 & 10 & 10 & 4 \\
\hline Gundelia tournefortii L. & 13 & 4 & 16 & 8 & 10 & 7 \\
\hline Lactuca tuberose Jacq. & 34 & 15 & 42 & 16 & 6 & 4 \\
\hline Linum pubescens Banks \& Sol. & 18 & 6 & 22 & 10 & 10 & 4 \\
\hline Lupinus pilosus L. & 15 & 7 & 28 & 11 & 12 & 7 \\
\hline Lycium europaeum L. & 32 & 5 & 16 & 6 & 6 & 4 \\
\hline Majorana syriaca (L.) Rafin. & 25 & 15 & 54 & 22 & 19 & 18 \\
\hline Mandragora autumnalis Bertol. & 11 & 5 & 22 & 6 & 6 & 5 \\
\hline Mentha spicata L. & 15 & 7 & 24 & 10 & 9 & 7 \\
\hline Notobasis syriaca (L.) Cass. & 14 & 7 & 31 & 8 & 6 & 5 \\
\hline Parietaria judiaca $L$. & 19 & 7 & 26 & 10 & 9 & 5 \\
\hline Paronychia argentea Lam. & $8 *$ & 4 & 16 & 6 & 6 & 4 \\
\hline Petroselinum sativum Hoffm. & 18 & 5 & 18 & 6 & 6 & 4 \\
\hline Phagnalon rupestre (L.) DC. & 30 & 9 & 31 & 13 & 12 & 9 \\
\hline Pinus halepensis Mill. & 50 & 8 & 16 & 14 & 6 & 4 \\
\hline Pistacia lentiscus L. & 12 & 8 & 28 & 11 & 10 & 7 \\
\hline Pyrus syriaca Boiss & 18 & 8 & 33 & 14 & 14 & 10 \\
\hline Reseda alba L. & 10 & 4 & 16 & 6 & 6 & 4 \\
\hline Rhus coriaria L. & 134 & 58 & 215 & 77 & 30 & 19 \\
\hline Ricinus communis $\mathrm{L}$. & 117 & 42 & 144 & 52 & 6 & 21 \\
\hline Rosa centifolia L. & 19 & 9 & 31 & 12 & 14 & 10 \\
\hline Rubia tenuifolia D'Urv. & 12 & 9 & 28 & 8 & 12 & 6 \\
\hline Ruta chalepensis L. & 11 & 4 & 16 & 6 & 10 & 5 \\
\hline Saccharum ravennae $\mathrm{L}$. & 11 & 7 & 28 & 10 & 6 & 5 \\
\hline Salvia fruticosa Mill. & 33 & 8 & 28 & 10 & 10 & 7 \\
\hline Salvia hierosolymitana Boiss. & 18 & 4 & 16 & 6 & 6 & 4 \\
\hline Sarcopoterium spinosum (L.) Sp. & 115 & 40 & 53 & 18 & 19 & 16 \\
\hline Satureja thymbra L. & 18 & 14 & 64 & 23 & 23 & 16 \\
\hline
\end{tabular}


Table 2. contd.

\begin{tabular}{lcccccc}
\hline Scabiosa prolifera L & 18 & 4 & 16 & 6 & 8 & 7 \\
Sinapis arvensis L. & 96 & 13 & 42 & 21 & 14 & 10 \\
Spinacia oleraceae L. & 43 & 7 & 28 & 10 & 10 & 5 \\
Styrax officinalis & 18 & 7 & 28 & 10 & 10 & 5 \\
Trigonella berythea Boiss \& Blanche & 11 & 8 & 39 & 6 & 6 & 4 \\
Varthemia iphionoides Boiss \& Blanche & 13 & 7 & 26 & 10 & 9 & 5 \\
Vicia faba L. & 8 & 12 & 44 & 16 & 15 & 11 \\
Viscum cruciatum Sieber \& Bioss & 25 & 36 & 149 & 23 & 8 & 9 \\
\hline
\end{tabular}

*Mean values for 10 strains; *, no acivity; IZD = $6 \mathrm{~mm}$.

Table 3. Number of plant species (range of inhibition zone diameters in $\mathrm{mm}$ )

\begin{tabular}{|c|c|c|c|c|c|c|}
\hline RAA & P. acnes & S. aureus & E. coli & P. aeruginosa & P. vulgaris & K. pneumonia \\
\hline No activity & $6\left(6^{\star}\right)$ & $11(6)$ & $15(6)$ & $15(6)$ & $18(6)$ & $18(6)$ \\
\hline$<30$ (Low activity) & $39(>6-10.8)$ & $41(7-16.7)$ & $20(6.3-8)$ & $39(6.7-12)$ & $37(6.7-12)$ & $38(6.1-13.9)$ \\
\hline 30-60(Medium activity) & $7(11.7-15.1)$ & $4(18.7-23.7)$ & $17(8.3-11)$ & $1(18)$ & $1(13.7)$ & 0 \\
\hline$\geq 60$ (High activity) & $4(20.8-25.1)$ & 0 & $4(12-22)$ & $1(22)$ & 0 & 0 \\
\hline
\end{tabular}

${ }^{*}$ Disc diameter $=6 \mathrm{~mm}$.

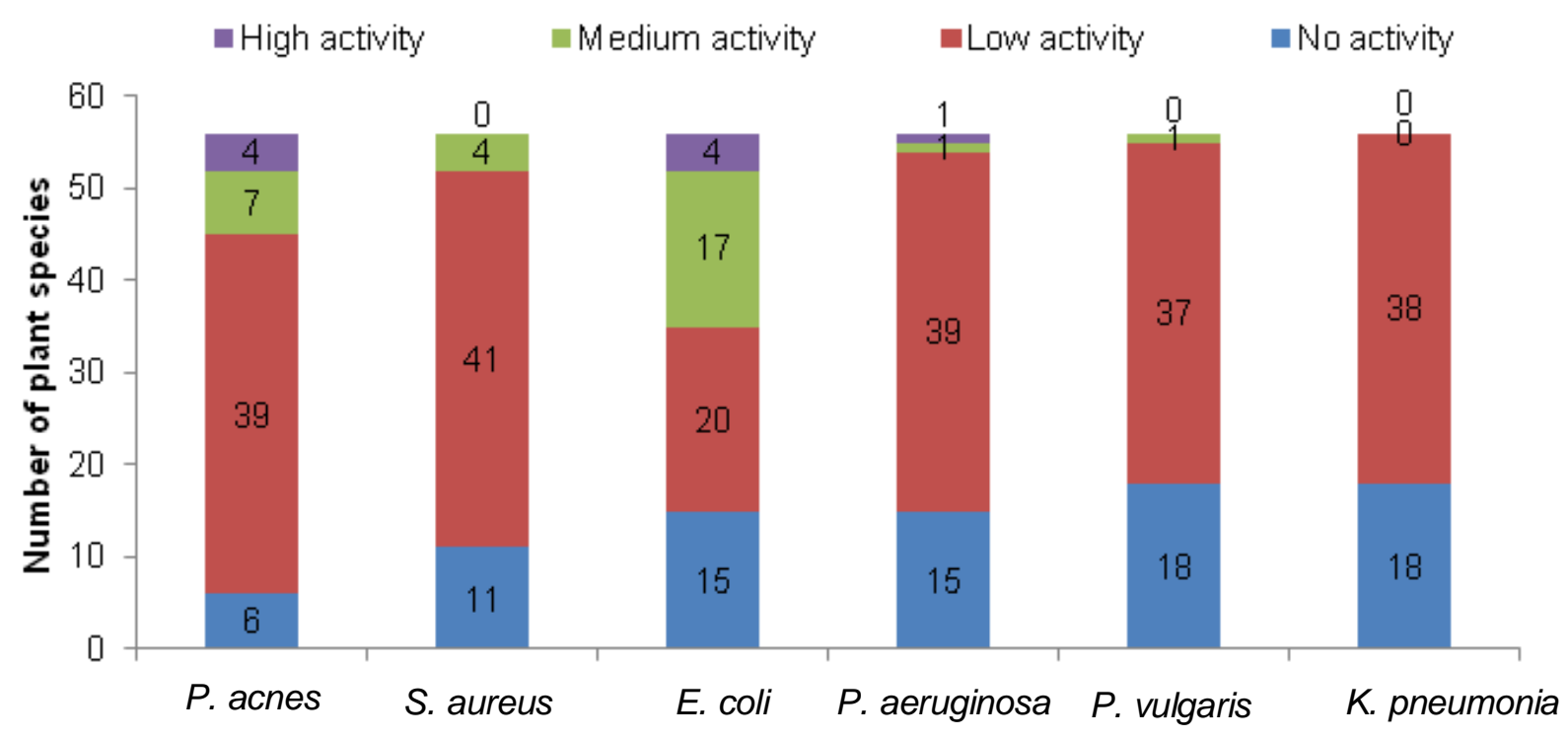

Figure 1. Number of plant spp by catagories of RAA against all test bacteria: no activity; low activity $<30$; medium, 30 to 60 ; high, $\geq 60$.

against $P$. acnes might justify the extensive use of these agents for the treatment of skin disorders.

Plants can be efficient in the treatment of acne vulgaris because of four mechanisms including anti-bacterial, antiinflammatory, anti-oxidant and anti-androgen activities (Azimi et al., 2012). The plants with essential oils (Baser et al., 2006; Peana et al., 1999), flavonoids (Takahashi et al., 2004), alkaloids (Takahashi et al., 2004), and phenolic compounds (Mishra et al., 2011) have antibacterial effects including inhibitory action against acne-inducing bacteria (Takahashi et al., 2004).

Among alkaloids, berberine also gives anti- inflammatory properties (Kumar et al., 2007). Phenolic compounds reveal a dose-dependent anti-oxidant activity that is directly related to the amount of total phenolic contents (Mishra et al., 2011). In addition, a polyphenol-rich extract 
Table 4. Propionibacterium acnes IZ (mm diam)*, RAA, MIC, and MBC (mg/ml) (mean values for 10 strains) for the most active plants.

\begin{tabular}{|c|c|c|c|c|}
\hline Plant & $\mathrm{IZ} \pm \mathrm{SE} \mathbf{E}^{\star \star}$ & RAA \pm SE & MIC \pm SE & MBC $\pm S E$ \\
\hline Ajuga orientalis & $11.7 \pm 0.16$ & $30.1 \pm 2.9$ & $20 \pm 0$ & $26 \pm 0.67$ \\
\hline Clematis cirrhosa & $10.7 \pm 0.1$ & $26 \pm 1.26$ & $25 \pm 0$ & $28.4 \pm 0.27$ \\
\hline Lactuca tuberosa & $12.4 \pm 0.16$ & $34 \pm 2.5$ & $20 \pm 0$ & $27.4 \pm 0.4$ \\
\hline Lycium europeum & $12 \pm 0$ & $32 \pm 0.0$ & $20 \pm 0$ & $25 \pm 0$ \\
\hline Majorana syriaca & $10.5 \pm 0.14$ & $24.8 \pm 1.93$ & $29 \pm 0.67$ & $31.6 \pm 0.27$ \\
\hline Phagnalon rupestre & $11.7 \pm 0.12$ & $30 \pm 2$ & $24.8 \pm 0.8$ & $24 \pm 0.67$ \\
\hline Pinus halepensis & $15 \pm 0.33$ & $50.3 \pm 6.5$ & $10 \pm 0$ & $15.2 \pm 0.53$ \\
\hline Rhus coriaria & $25 \pm 0.21$ & $133.6 \pm 13.8$ & $6 \pm 0$ & $6 \pm 0$ \\
\hline Ricinus communis & $23 \pm 0.33$ & $117 \pm 10$ & $6 \pm 0$ & $10 \pm 0$ \\
\hline Salvia fruticosa & $12.3 \pm 0.28$ & $33.4 \pm 4.5$ & $16.2 \pm 0.13$ & $10 \pm 0$ \\
\hline Sarcopoterium spinosum & $22.8 \pm 0.34$ & $114.5 \pm 10.2$ & $6 \pm 0$ & $21.6 \pm 0.27$ \\
\hline Sinapis arvensis & $20.8 \pm 0.21$ & $96.4 \pm 5$ & $10 \pm 0$ & $23 \pm 0$ \\
\hline Sonchus oleraceus & $14 \pm 0$ & $43 \pm 0.0$ & $10 \pm 0$ & $16 \pm 0$ \\
\hline Viscum cruciatum & $10.7 \pm 0.10$ & $25.2 \pm 1.47$ & $25.6 \pm 0.4$ & $31.6 \pm 0.27$ \\
\hline Reference antibiotic $*$ (10 mg/disc) & $21.3 \pm 0.8$ & & & \\
\hline
\end{tabular}

* Disc diameter, 6 (mm); ** standard error (SE); * chloramphenicol.

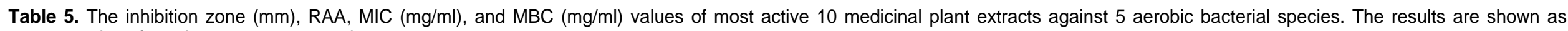
average values from three separate experiments.

\begin{tabular}{|c|c|c|c|c|c|c|c|c|c|c|c|c|c|c|c|c|c|c|c|c|}
\hline \multirow{2}{*}{ Plant } & \multicolumn{4}{|c|}{ S. aureus } & \multicolumn{4}{|c|}{ E. coli } & \multicolumn{4}{|c|}{ P. aeruginosa } & \multicolumn{4}{|c|}{ P. vulgaris } & \multicolumn{4}{|c|}{ K. pneumonia } \\
\hline & RAA & IZ & MIC & MBC & RAA & IZ & MIC & MBC & RAA & IZ & MIC & MBC & RAA & IZ & MIC & MBC & RAA & IZ & MIC & MBC \\
\hline Crataegus aronia & 15 & $12 \pm 0.3$ & $15 \pm 0$ & $18 \pm 0$ & 44 & $10 \pm 0$ & $20 \pm 0$ & $25 \pm 0$ & 23 & $12 \pm 0$ & $20 \pm 0.33$ & $25 \pm 0.33$ & 16 & $10 \pm 0$ & $20 \pm 0.33$ & $25 \pm 0$ & 11 & $10 \pm 0$ & $20 \pm 0$ & $25 \pm 0$ \\
\hline Lactuca tuberosa & 15 & $12 \pm 0$ & $20 \pm 0$ & $20 \pm 0$ & 42 & $9.3 \pm 0.3$ & $25 \pm 0$ & $30 \pm 0$ & 16 & $10 \pm 0$ & $20 \pm 0.33$ & $25 \pm 0.33$ & 6 & $6 \pm 0$ & $>25$ & $>30$ & 4 & $6 \pm 0$ & $>25$ & $>30$ \\
\hline Majorana syriaca & 15 & $12 \pm 0$ & $15 \pm$ & $21 \pm 0.67$ & 54 & $11 \pm 0$ & $14 \pm 0.33$ & $21 \pm 0.67$ & 22 & $11.7 \pm 0.3$ & $14 \pm 0$ & $20 \pm 0$ & 19 & $11 \pm 0$ & $12 \pm 0$ & $20 \pm 0$ & 18 & $12.7 \pm 0.3$ & $15 \pm 0.67$ & $20 \pm 0.33$ \\
\hline Rhus coriaria & 58 & $23.7 \pm 0.3$ & $4 \pm 0$ & $6 \pm 0$ & 215 & $22 \pm 0$ & $6 \pm 0$ & $8 \pm 0$ & 77 & $22 \pm 0$ & $4 \pm 0$ & $6 \pm 0.33$ & 30 & $13.7 \pm 0.3$ & $15 \pm 0$ & $18 \pm 0$ & 19 & $13 \pm 0$ & $20 \pm 0$ & $25 \pm 0$ \\
\hline Ricinus communis & 42 & $20 \pm 0$ & $8 \pm 0$ & $10 \pm 0$ & 144 & $18 \pm 0$ & $14 \pm 0.67$ & $16 \pm 0$ & 52 & $18 \pm 0.7$ & $14 \pm 0$ & $16 \pm 0$ & 6 & $6 \pm 0$ & $>25$ & $>30$ & 21 & $13.9 \pm 0.3$ & $12 \pm 0.67$ & $15 \pm 0$ \\
\hline Sarcopoterium spinosum & 40 & $19.7 \pm 0.3$ & $8 \pm 0$ & $10 \pm 0$ & 53 & $11 \pm 0$ & $19 \pm 0.67$ & $20 \pm 0$ & 18 & $10.7 \pm 0.3$ & $17 \pm 0.67$ & $18 \pm 0$ & 19 & $11 \pm 0$ & $18 \pm 0$ & $20 \pm 0$ & 16 & $12 \pm 0$ & $18 \pm 0$ & $20 \pm 0$ \\
\hline Satureja thymbra & 14 & $11.7 \pm 0.3$ & $11 \pm 0.33$ & $16 \pm 0.33$ & 64 & $12 \pm 0$ & $12 \pm 0$ & $16 \pm 0$ & 23 & $12 \pm 0$ & $12 \pm 0.67$ & $17 \pm 0.67$ & 23 & $12 \pm 0$ & $12 \pm 0$ & $16 \pm 0$ & 16 & $12 \pm 0$ & $11 \pm 0.33$ & $16 \pm 0$ \\
\hline Vicia faba & 12 & $10.7 \pm 0.3$ & $18 \pm 0.33$ & $20 \pm 0.33$ & 44 & $10 \pm 0.6$ & $20 \pm 0$ & $25 \pm 0$ & 16 & $10 \pm 0$ & $20 \pm 0$ & $25 \pm 0$ & 15 & $9.7 \pm 0.3$ & $20 \pm 0$ & $25 \pm 0$ & 11 & $10 \pm 0$ & $20 \pm 0$ & $25 \pm 0$ \\
\hline Viscum cruciatum & 36 & $18.7 \pm 0.3$ & $11 \pm 0.67$ & $12 \pm 0$ & 149 & $18.3 \pm 0.3$ & $8 \pm 0$ & $10 \pm 0$ & 23 & $12 \pm 0$ & $20 \pm 0$ & $25 \pm 0$ & 8 & $7 \pm 0$ & $>25$ & $>30$ & 9 & $9 \pm 0$ & $25 \pm 0$ & $30 \pm 0$ \\
\hline Reference antibiotic & & $31 \pm 0.6$ & & & & $15 \pm 0$ & & & & $25 \pm 0$ & & & & $25 \pm 0$ & & & & $30 \pm 0$ & & \\
\hline
\end{tabular}


shows anti-androgen effect (Park et al., 2004; Dobrev, 2007). Bisnaphthquinones exhibit remarkable testosterone 5-alpha-reductase inhibitory activity (Gopal and Farahana, 2001).

Xanthohumol and the lupulones have inhibitory activities against acne-inducing bacteria $(P$. acnes, $S$. epidermidis and $S$. aureus), whereas xanthohumol exhibits higher activity in total oxygen radical absorbance capacity as well as single oxygen absorbance capacity (Yamaguchi et al., 2009). The three unsaturated fatty acids (oleic acid, linoleic acid and $y$-linolenic acid) inhibit testosterone 5a-reductase action (Norimoto et al., 2010). Hence, combination use of $R$. coriaria, $S$. arvensis, Pinus halepensis can be so effective because they include essential oils, flavonoids, alkaloids, phenolic compound, fatty acids, etc, and have significant anti-bacterial, antiinflammatory, anti-oxidant, and anti-androgen activities.

Studies on cell lines revealed that flavonoid, alkaloid, essential oil, phenol and phenolic compound, tannin, xanthone and xanthone derivative, and the bisnaphthquione derivative are effective in the treatment of acne (Azimi et al., 2012). Animal studies showed that diterpene acid, phenylpropanoid glycosides, acteoside and flavonoids have anti-inflammatory activity.

Literature review on the phytochemical constituents of the active plants in this study revealed that $R$. coriaria contains protocatechuic acid, isoquercitrin, and myricetin3-0-a-L-rhamnoside (Shabana et al., 2011). Similarly, tannins, saponins, alkaloids, carbohydrates, phenols, flavonoids, sterols and resins are the major components of $R$. communis (Sundarasivarao et al., 1977; Rao et al., 1986; Biswas et al., 2002; Kensa and Yasmin, 2011). The presence of Catechin and epicatechin in S. spinosum (Rao et al., 2010), 1-butenyl isoithiocyanate, cubenol, dimethyl trisulfide, dimethyl tetrasulfide, octadecane, 6 , 10, 14-tri methyl pentadecane-2-one and indole in $S$. arvensis (Al-Qudah et al., 2011), and caryophyllene oxide, thumbergol, and humulene oxide in Pinus halepensis (Abi-Ayad et al., 2011) has been reported.

The essential oil composition of $S$. thymbra comprises the following main constituents: carvacrol, thymol, $p$ cymene, and $\gamma$-terpinene, and very rarely $\alpha$-pinene and sabinene (Giweli et al., 2012).

In addition, recent studies have indicated herbal medicines that are strong antioxidants and have many positive effects in oxidant related diseases (HasaniRanjbar et al., 2009). Among these strong antioxidants, Satureja (Momtaz and Abdollahi, 2010), Teucrium (Hasani-Ranjbar et al., 2010) or Urtica (Mehri et al., 2011) species can be numbered as those that remain to be examined in he management of acne vulgaris.

Interestingly, $R$. coriaria extract showed promising antibacterial activities against both $P$. acnes and all aerobic bacteria with the exception of $K$. pneumonia. Also, $R$. communis showed similar activities against all test bacteria except $P$. vulgaris. Our results are in agreement with those of other researches which indi- cated a strong inhibitory effect of $R$. communis and $R$. coriaria against different microorganisms including E. coli, S. aureus, and B. subtilis (Pesaramelli et al., 2012; Dulger and Gonuz, 2004). Being crude extracts, the overall antimicrobial activity screening results are still indicative of the potential of these herbal drugs as effective medicaments in the treatment of infectious skin disorders.

Based on the initial antimicrobial screening test, the most active plant extracts against bacterial strains were selected for further studies for the determination of MIC and MBC. These values indicate that the extracts of $R$. coriaria were the most potent against $P$. acnes, $S$. aureus, E. coli, $P$. aeruginosa. Similarly, extracts of Satureja thymbra was found to be potent against $P$. vulgaris and $K$. pneumonia. The results are in agreement with the initial antimicrobial screening test results.

The lowest MIC value observed was $4 \mathrm{mg} / \mathrm{ml}(\mathrm{MBC}=6$ $\mathrm{mg} / \mathrm{ml})$, which was the MIC value of the hydroalcoholic extracts of $R$. coriaria on $S$. aureus and $P$. aeruginosa. On the other hand, the highest MIC value (amongst the most active plant extracts) was registered for $K$. pneumoni (the least sensitive bacterial strain) to the crude extracts of $V$. crusiatum.

In conclusion, all the plants investigated possessed activity against at least one strain of bacteria. The extensive use of these herbal drugs by the local people in treating various types of skin disorders might therefore be justified by their antimicrobial activities against different strains of bacteria, which are known to be responsible for causing various skin infections. The results also indicate that scientific studies carried out on medicinal plants having traditional claims of effectiveness might warrant fruitful results. Further studies aimed at the isolation and identification of active substances could also disclose compounds with better therapeutic value.

\section{REFERENCES}

Abi-Ayad M, Abi-Ayad FZ, Lazzouni HA, Rebiahi SA, Ziani-Cherif C, Bessiere (2011). Chemical composition and antifungal activity of Aleppo pine essential oil. J. Med. Plants Res. 5:5433-5436.

Ali-Shtayeh MS, Abu-Ghdaib SI (1999). Antifungal activity of plant extracts against dermatophytes. Mycoses 42:665-672.

Ali-Shtayeh MS, Jamous Rana M (2002). "Red list of threatened plants" of the West Bank and Gaza Strip and role of botanic gardens in their conservation. Biodivers. Environ. Sci. Stud. 2:1-47.

Ali-Shtayeh MS, Jamous Rana M (2006). Ethnobotany of Palestinian herbal medicine in the northern West Bank and Gaza Strip: review and comprehensive field study. Biodivers. Environ. Sci. Stud. Ser. $4: 1-122$.

Ali-Shtayeh MS, Jamous Rana M (2008). Traditional Arabic Palestinian Herbal Medicine, TAPHM. Til, Nablus, Palestine, Biodiversity and Environmental Research Center, BERC.

Ali-Shtayeh MS, Jamous Rana M, Jamous Rania M (2011). Herbal preparation use by patients suffering from cancer in Palestine.

Complement. Ther. Clin. Pract. 17(4):235-240. http://dx.doi.org/10.1016/j.ctcp.2011.06.002

Ali-Shtayeh MS, Jamous Rania M, Jamous Rania M (2012). Complementary and Alternative Medicine use amongst Palestinian diabetic patients. Complement. Ther. Clin. Pract. 18:16-21. 
doi:10.1016/j.ctcp.2011.09.001

Ali-Shtayeh MS, Jamous RM, Hamad AKh (2003a). Guide to trees and shrubs from Palestine. Til, Nablus: Biodiversity and Environmental Research Center (BERC). In Arabic with English summary.

Ali-Shtayeh MS, Yaghmour Reem M-R, Faidi YR, Salem Kh, Al-Nuri MA (1998). Antimicrobial activity of twenty medicinal plants used in folkloric medicine in the Palestinian area. J. Ethnopharmacol. 60:265271.

Ali-Shtayeh MS, Yaniv Z, Mahajna J (2000). Ethnobotanical survey in the Palestinian area: A classification of the healing potential of medicinal plants. J. Ethnopharmacol. 73:221-232.

Ali-Shtayeh MS, Zayed RA, Jamous RM (2003b). Palestinian plants as a source of antimycotics. In: M.K. Rai and D. Mares (Editors) Plant derived antimycotics. Binghamton: The Haworth Press. pp. 399-427.

Alonso R, Fernandez-Aranguiz A, Colom K, Herreras A, Cisterna R (2000). Profile of bacterial isolates and antimicrobial susceptibility: Multicenter study using a one-day cut-off. Revista Espanola de Quimioterapia 13:384-393.

Al-Qudah MA, Al-Jaber HI, Muhaidat R, Hussein El, Abdel Hamid A, AlSmadi ML, Abaza IF, Afifi FU, Abu-Orabi ST (2011). Chemical composition and antimicrobial activity of the essential oil from Sinapis alba L. and Sinapis arvensis L. (Brassicaceae) growing wild in Jordan. Res. J. Pharm. Biol. Chem. Sci. 2:1136-1144.

Arda $\mathrm{H}$ (2009). Acne vulgaris between dermatology patients in Palestine 2000-2009. Paper presented at Adolescent and youth health: Development and Future challenges conference. Nablus- An-Najah National University.

Azimi H, Fallah-Tafti M, Khakshur AA, Abdollahi M (2012). A review of phytotherapy of acne vulgaris: Perspective of new pharmacological treatments. Fitoterapia doi: 10.1016/j.fitote.2012.03.026

Baron EJ, Peterson LR, Finegold SM (1994). Methods for testing antimicrobial effectiveness. In: Bailey and Scott's diagnostic microbiology, 9th ed. St. Louis: Mosby-Year Book, Inc. pp. 168-193.

Baser KH, Demirci B, Iscan G, Hashimoto T, Demirci F, Noma Y, et al. (2006). The essential oil constituents and antimicrobial activity of Anthemis aciphylla BOISS. var. discoidea BOISS. Chem. Pharm. Bull. (Tokyo) 2006; 54:222-5.

Biswas KI, Chattopadhyay A, Banerjee YA (2002). Biological activities and medicinal properties of neem. Bandopadhyay. U. Curr. Sci. 82:1336-1345.

Borris RP (1996). Natural products research: perspectives from a major pharmaceutical company. J. Ethnopharmacol. 51:29-38.

Crowfoot G, Hand M, Baldensperger L (1932). From cedar to hyssob: A study in the folklore of plants in Palestine. London: Sheldon Press.

Dobrev $\mathrm{H}$ (2007). Clinical and instrumental study of the efficacy of a new sebum control cream. J. Cosmet. Dermatol. 6:113-8.

Dulger B, Gonuz A (2004). Antimicrobial activity of some Turkish medicinal plants. Pakistan. J. Biol. Sci. 7:1559-1562.

Gediya SK, Mistry RB, Patel UK, Blessy M, Jain HN (2011). Herbal plants: used as a cosmetics. J. Nat. Prod. Plant Resour. 1: 24-32.

Ghosh VK, Nagore DH, Kadbhane KP, Patil MJ (2011). Different approaches of alternative medicines in acne vulgaris treatment. Orient. Pharm. Exp. Med. 11:1-9.

Giweli A, Džamić AM, Soković M, Ristić MS, Marin PD (2012). Antimicrobial and Antioxidant Activities of Essential Oils of Satureja thymbra Growing Wild in Libya. Molecules 17:4836-4850.

Gopal MG, Farahana B (2001). Effectiveness of herbal medications in the treatment of acne vulgaris-a pilot study. Ind. Practitioner 54:723-7.

Hamburger M, Hostettmann K (1991). Bioactivity in plants: the link between phytochemistry and medicine. Phytochemistry 30:3864-74.

Hasani-Ranjbar S, Larijani B, Abdollahi MA (2009). Systematic review of the potential herbal sources of future drugs effective in oxidantrelated diseases. Inflamm. Allergy Drug Targets 8(1):2-10.

Hasani-Ranjbar S, Nayebi N, Larijani B, Abdollahi MA (2010). Systematic review of the efficacy and safety of Teucrium species; from anti-oxidant to anti-diabetic effects. Int. J. Pharmacol. 6(4):31525.

Hayes AJ, Markovic B (2002). Toxicity of Australian essential oil Backhousia citriodora (Lemon myrtle). Part 1. Antimicrobial activity and in vitro cytotoxicity. Food Chem. Toxicol. 40:535-543.

Hodges N (2002). Pharmaceutical applications of microbiological techniques In: Aulton, M.E. (Ed.), Pharmaceutics: The Science of Dosage Form Design, 2nd ed. Harcourt Publishers Limited, London. pp. 606.

Irobi ON, Daramala SO (1994). Bactericidal properities of crude extracts of Mitracarpus villous. Ethnopharmacology 42:39-43.

Kensa VM, Yasmin S (2011). Phytochemical screening and antibacterial activity on Ricinus communis L. Plant Sci. Feed 1:167-173.

Khalilia W (2001). Medicinal Plants as a source of therapeutics for the Treatment of Hormone-Refractory Prostate Cancers. MSc. Thesis, An-Najah University, Nablus.

Kumar GS, Jayaveera KN, Ashok CK, Sanjay PU, Swamy BMV, Kishore Kumar DV (2007). Antimicrobial effects of Indian medicinal plants against acne-inducing bacteria. Trop. J. Pharm. Res. 6:717-23.

Law MP, Chuh AA, Lee A, Molinari N (2010). Acne prevalence and beyond: acne disability and its predictive factors among Chinese late adolescents in Hong Kong. Clin. Exp. Dermatol. 35:16-21.

Mehri A, Hasani-Ranjbar S, Larijani B, Abdollahi MA (2011). Systematic review of efficacy and safety of Urtica dioica in the treatment of diabetes. Int. J. Pharmacol. 7(2):161-70.

Mishra A, Kumar S, Bhargava A, Sharma B, Pandey AK (2011). Studies on in vitro antioxidant and antistaphylococcal activities of some important medicinal plants. Cell. Mol. Biol. (Noisy-le-Grand) 57:1625.

Momtaz S, Abdollahi M (2010). An update on pharmacology of Satureja species; from antioxidant, antimicrobial, antidiabetes and antihyperlipidemic to reproductive stimulation. Int. J. Pharmacol. 6(4):454-61.

Murray PR, Baron EJ, Pfaller MA, Tenover FC, Yolke RH (1995). Manual of Clnical Microbiology. (6th ed). USA: ASM Press. pp. 15261543.

Norimoto H, Nakajima K, Yomoda S, Morimoto Y (2010). Testostrone 5alphareductase inhibitory consituents from the fruits of Rosa multiflora Thunb. J. Trad. Med. 27:90-95.

Nostro A, Germano MP, D'Angelo V, Marino A, Cannatelli MA (2000). Extraction methods and bioautography for evaluation of medicinal plant antimicrobial activity. Lett. Appl. Microbiol. 30:379-384.

Oprika C (2006). Characterisation of antibiotic-resistant Propionibacterium acnes from acne vulgaris and other diseases. Stockholm: Karolinska University.

Park J, Lee J, Jung E, Park Y, Kim K, Park B, Jung K, Park E, Kim J, Park D (2004). In vitro antibacterial and anti-inflammatory effects of honokiol and magnolol against Propionibacterium sp. Eur. J. Pharmacol. 496:189-95.

Peana AT, Moretti MD, Juliano C (1999). Chemical composition and antimicrobial action of the essential oils of Salvia desoleana and $S$. sclarea. Planta. Med. 65:752-4.

Pesaramelli K, Vellanki J, Keerthi DV, Chaitanya Sravanthi K (2012). Evaluation of antibacterial activity of herbs. Int. Res. J. Pharm. 3(8):230-232.

Rademaker M, Garioch JJ, Simpson NB (1989). Acne in schoolchildren: no longer a concern for dermatologists. Br. Med. J. 298:1217-19.

Rao DVR, Sing K, Chopra P, Chabra P, Ramanujahi G (1986). In vitro bactericidal activity of neem oil, Indian J. Med. Res. 84:314-316.

Rao MU, Sreenivasulu M, Chengaiah B, Reddy KJ, Chetty CM (2010). Herbal Medicines for Diabetes Mellitus: A Review. Int. J. Pharm. Tech. Res. 2:1883-1892.

Sader HS, Jones RN, Silva JB (2002). Skin and soft tissue infections in Latin American Medical Centers: four-year assessment of the pathogen frequency and antimicrobial susceptibility patterns. Diagn. Microbiol. Infect. Dis. 44:281-288.

Scheinfeld NS (2007). Acne: a review of diagnosis and treatment. P \& T 32:340-347.

Shabana MM, El Sayed AM, Yousif MF, El Sayed AM, Sleem AA (2011). Bioactive constiuents from Harpephyllum caffrum Bernh. and Rhus coriaria L. Pharmacogn. Mag. 7:298-306.

Singh D, Hatwar B, Nayak S (2011). Herbal plants and Propionibacterium acnes: An overview. Int. J. Biomed. Res. 2:486498.

Sundarasivarao B, Nazma A, Madhusudhanarao J (1977). Antifungal activity of gedunin. Curr. Sci. 46:714-716.

Takahashi T, Kokubo R, Sakaino M (2004). Antimicrobial activities of eucalyptus leaf extracts and flavonoids from Eucalyptus maculata. 
Lett. Appl. Microbiol. 39:60-64.

Toyoda M, Morohashi M (2001). Pathogenesis of acne. Med. Electron. Microsc. 34:29-40.

Williams HC, Dellavalle RP, Garner S (2012). Acne vulgaris. Lancet 28;379(9813):361-72. doi: 10.1016/S0140-6736(11)60321-8.

Yahya $H$ (2009). Acne vulgaris in Nigerian adolescents-prevalence, severity, beliefs, perceptions, and practices. Int. J. Dermatol. 48:498505.

Yamaguchi N, Satoh-Yamaguchi K, Ono M (2009). In vitro evaluation of antibacterial, anticollagenase and antioxidant activities of hop components (Humulus lupulus) addressing acne vulgaris. Phytomedicine 16:369-376.
Yasin R (2008). Studies on Folkloric Medicinal Plants Used by Palestinians in the Qalqilia District. MSc. Thesis, An-Najah University, Nablus. 